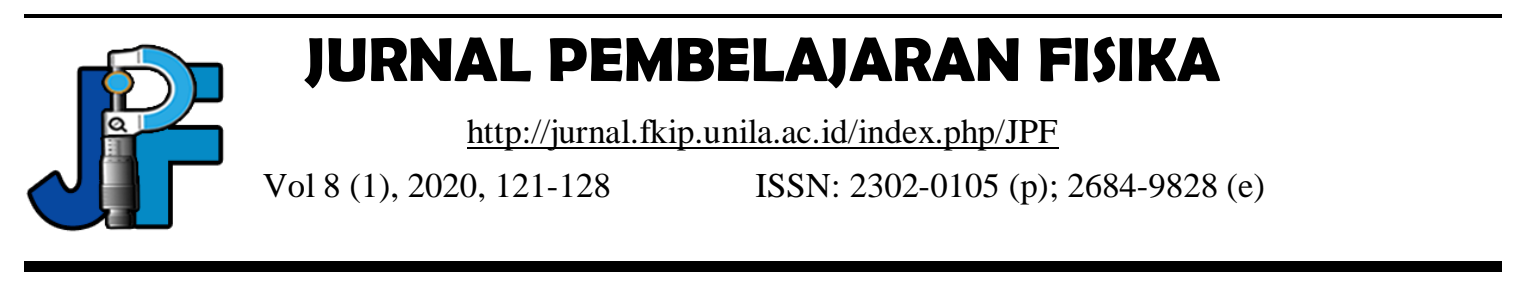

\title{
Descriptive Qualitative Analysis Based on Physics Mental Model of Students' Cognitif Understanding on the Concepts of Kinematics Particle and Parabolic Motion
}

\author{
Nyoman Rohadi*, Iwan Setiawan, Eko Swistoro \\ Department of Physics Education, Bengkulu University, Indonesia \\ *e-mail:rohadi_nyo@yahoo.com
}

\begin{abstract}
This article portrays descriptive analysis results based on a physics mental model toward the cognitive reasoning of the first semester students in the year of study 2019/2020 in the physics education study program of the JPMIPA FKIP Bengkulu University on the concepts of kinematics particle and parabolic motion. The analyzed data were a pretest, students worksheets (SWS), and posttest data Of 28 students who participated in basics physics, one class. There was a different score between the mean score of the pretest and the posttest data. The mean score of the pretest data was 45.21 in a range score of 30.00-80.00 and the mean score of the posttest data was 72.50 in a range score of 50.00-100.00. The descriptive analysis of the pretest data and the SWS data indicated that there was a low cognitive competency among the students in understanding the physics diagram and solving physics graphs related problems. But no student found any difficulty in using physics equations on solving the uniform motion problems. Even though some students failed in solving the amount of acceleration related problems. Student's cognitive reasoning sounds good on the posttest data. Most of the students could apply the physics mental model on solving conceptual, diagram, graph, and mathematicsrelated physics problems.
\end{abstract}

Keywords: Mental model, Cognitive reasoning, Arihtmatics particle, Parabolics motion.

DOI: http://dx.doi.org/10.23960/jpf.v8.n1.202012 


\section{INTRODUCTION}

Understanding basic physics course material is still considered difficult by most of the first semester students in the first college year. Although in general the concepts of physics are learned, according to the syllabus of higher education is not so different from the material that was studied at the high school level. This situation can be caused by the understanding of physics possessed by high school graduates who have not formed completely in connection with the learning process of physics in schools that are less structured and have not formed a complete mental model of physics thinking. It can be said that these students have not reached the level of mastery learning physics. The usefulness of the model in the development of natural science varies greatly. There are two main functions about the concept of the model, namely: (1) the model allows to facilitate the understanding of a natural phenomenon in an effort to centralize attention on the characteristics of these phenomena, and (2) the model can provide stimuli to carry out studies and support visualization efforts of a symptom and focused on understanding the symptom (Gilbert et al., 1980).

The mental model of thinking physics is very necessary when discussing concepts and physical phenomena considering the physical phenomena discussed in physical science are presented with various forms of mental thinking models in order to facilitate someone in understanding physics (Khasanah et al., 2016). Mental models can help someone to predict how a system works or predict how a problem can be solved. The more precise and complete mental models used, one's ability to predict is stronger so that it can develop scenarios that might be suitable for the situation at hand (Priyadi et al., 2018).

The ability to predict can function as a differentiator for mental models of other cognitive structures that do not include in the new situation that a person faces. Thus building mental models in learning physics should be able to help students to overcome difficulties in learning physics (Gentner \& Stevens, 1983). The difficulty of understanding the basic concepts of physics is also referred to as the cognitive constraints of physics (Rohadi, 2011). In the learning process some students have difficulty in developing thinking skills for example in connecting their conceptual understanding with understanding diagrammatic models, graph models and mathematical models (Rohadi, 2012).

Some previous studies on cognitive constraints and difficulty understanding mental models on basic physics concepts were conducted on physics education students (Rohadi et al., 2003); (Koto, 2004); (Swistoro, 2007); (Rohadi, 2011); (Rohadi, 2012)). Besides that, mapping mental models through the study of diagnostic test results also reported by Amrizaldi, et al (2014) (Amrizaldi et al., 2014). The results of the study in the form of mental model studies predicting the learning of refraction of light reported by (Herlina et al., 2014). The results of studies on students' mental models of Newton's laws were also reported by (Rahayu \& Purwanto, 2013). To build mental models and improve learning outcomes can be done using SWS (student worksheets) carried out in groups through class discussions in training connecting mental physics models (Trianto, 2012). Rohadi \& Setiawan (2019) reported the results of their research in improving students' cognitive competence through direct learning of kinematics particle based on mental models. So the complete learning of basic physics is very important, because 
good understanding on fundamental physical concepts is needed in developing knowledge in advanced physics courses that are more complex and require analytical thinking skills (Rohadi \& Setiawan, 2019). In accordance with the description above, a descriptive analysis based on physics mental model has been crried out on cognitif understanding of the first semester students at the physics education study program FKIP Bengkulu University on the concepts of kinematics particle and parabolic motion. The results should be of beneficial for lecturers in order to apply inovative andefective methods and strategics in conducting basics physics classroom.

\section{METHOD}

Descriptive analysis based on mental physics models includes studies on (1) conceptual understanding of physics, (2) understanding of physics diagrams, (3) understanding of physics graphs, and (4) application of physics equations. The study was conducted on cognitive understanding of the first semester students of basic physics I in physics education study program at JPMIPA FKIP Bengkulu University in the year study o 2019/2020. The subject participated in the reaserch was taken by purpossive sampling intact class data. The descriptive analysis is directed to examine the qualitative result data to explore pedagogical of student's physics reasoning (Wiersma, 1986). The three instruments which were pretest, SWS, and posttest each consists of 5 numbers physics problems in the form of conceptual, diagram, graph, and mathematical problems. The SWS instrument was in the form of essay problems. The pretest and the posttest were in the form of multiple choice test. Descriptive analysis based on mental physics models is carried out on the cognitive understanding of students based on the results of the pretest data, SWS data, and the posttest data. The analysis was conducted based on the type of understanding, cognitive competence, and elements that were fulfilled as shown in table 1.

Table 1. Elements of cognitive competency analysis based on the physics mental models

\begin{tabular}{ccc}
\hline $\begin{array}{c}\text { Type of } \\
\text { Understanding }\end{array}$ & Cognitive competence & The elements that are fulfilled \\
\hline $\begin{array}{c}\text { Conceptual } \\
\text { physics }\end{array}$ & Mention, state and explain & $\begin{array}{c}\text { Definition, law and theoretical } \\
\text { physics }\end{array}$ \\
Physics diagram & State, Make, Write, and describe & $\begin{array}{c}\text { line, point, letter symbol, quantity } \\
\text { symbol, vector, quantity magnitude, } \\
\text { unit, and object symbol } \\
\text { Physics graph }\end{array}$ \\
Cartesian axis lines, relationship \\
Physics formula
\end{tabular}




\section{RESULT AND DISCUSSION}

\section{Results of the Study on Pretest}

The men score achieved by 28 students on the pretest was 44.64 , the loiwest score was 30,00 and the highest score was 80,00. The score on the pretest showed a slightly wide range data. This situation shows that the students' cognitive understanding on physics phenomena according to physics mental model of reasoning is still and very varied. Table 2 addresses the percentage of students who answered correctly on pretest questions according to the shape of the problem and the cognitive level of Bloom's taxonomy.

Table 2. Percentage of number students answering correctly based on cognitive level

\begin{tabular}{cccc}
\hline $\begin{array}{c}\text { Form of the } \\
\text { problem }\end{array}$ & Cognitif level & Number of student & Percentage \\
\hline Physics concept & C2 & 13 & 46,42 \\
Physics diagram & C2 and C3 & 11 & 39,28 \\
Physics graph & C3 and C4 & 10 & 35,71 \\
Physics formula & C3 & 16 & 57,14 \\
\hline
\end{tabular}

Further examination from students' answering on the pretest questions, it appears that a large number of students still cannot understand correctly the physical phenomena associated with GLB (uniform linear motion), GLBB (uniform accelerated motion), and parabolic motion. Likewise, its ability to understand the magnitude relationship graphically is still low. However, most students already have an understanding on mathematical relationships. In the pretest, students in general can answer questions using physics formulas. These results are consistent with research reports by Rohadi, et al (2003) and Herlina, et al (2018) that most students more easily apply physics formulas than understanding diagrams and graphs. The results of the study in this pretest are in line with the mapping of mental models through the study of diagnostic test results reported by Amrizaldi, et al, (2014).

\section{Results of the Study on SWS (student worksheet)}

The results of student group work on SWS on 3 physics concepts in accordance with the assessment criteria on SWS are shown in table 3.

Table 3. Student Sectors in SWS Based on Groups in 3 Physics Concepts

\begin{tabular}{ccccc}
\hline $\begin{array}{c}\text { Number of } \\
\text { groups }\end{array}$ & Concepts & Mean score & Lowest score & Highest score \\
\hline 7 & GLB & 70,00 & 60,00 & 75,00 \\
7 & GLBB & 85,00 & 50,00 & 100,00 \\
7 & Parabolic motion & 70,00 & 50,00 & 75,00 \\
\hline
\end{tabular}

The state of the score range of students according to their group in SWS 1 on the GLB concept is not too wide as shown in table 2, with the lowest average scores and the highest score. This shows that the cognitive abilities of students in the uniform motion concept using mental physics models are at a sufficient category. The state of the score range of students according to their group in SWS 2 on the GLBB concept is not so 
wide as indicated by the average score, the lowest score and the highest score. This shows that the cognitive abilities of students in physical phenomena using the mental physics model are at a sufficient category. The state of the range of scores of students according to their group in SWS 3 on the concept of parabolic motion is also not too wide as indicated by the average value, lowest score and highest score. This shows that as a group the cognitive abilities of students on these three concepts using mental physics models are good enough. The same thing also reported that student learning outcomes using POE-based worksheets were higher than conventional worksheets (Nurhidayati et al., 2017).

Further studies on the results of student work according to groups in SWS GLB and GLBB concepts show a lack of mastery of students in understanding the importance of using symbols (i.e: magnitude symbols, marking point positions, vector directions, and units) in making physics drawing diagrams. Students also still have difficulty in making 2 magnitude relationship graphs namely speed and time relationship graphs or v-t graphs. In general, students have no difficulty in applying formulas in answering physics problems with the GLB concept. But there are number of students who are still difficult to determine the amount of acceleration in the GLBB problem. These results are consistent with the results of research on students' mental models of Newton's laws reported by Rahayu and Purwanto (2013). Further descriptive analysis of the results of student work according to groups in SWS parabolic concept shows an increase in student mastery in understanding the importance of using symbols (i.e: quantities, vectors) in making physics drawing diagrams. Students are already good at making velocity graphs on the $\mathrm{y}$ and $\mathrm{x}$ axis (i.e: expressing velocity projection $\mathrm{v}$ for the sine and cosine components). In general, students have no difficulty in applying formulas to express the velocity on a parabolic motion trajectory and calculate the object's distance to time on the $\mathrm{y}$ axis and $\mathrm{x}$ axis.

\section{Results of the Study on Posttest}

The average score achieved by 28 students in the 71.42 post-test results with a range of scores of 50.00-100. The score on the posttest shows a quite wide range data. This situation shows that the cognitive understanding of students in the posttest of the three concepts according to the mental physics model has increased but still varies.

Table 4 . The percentage of students who answered correctly at the posttest according to the form of questions and cognitive taxonomy level of Bloom.

\begin{tabular}{cccc}
\hline $\begin{array}{c}\text { Form of the } \\
\text { problem }\end{array}$ & Cognitif level & Number of student & Percentage \\
\hline Physics concept & C2 & 22 & 78,57 \\
Physics diagram & C2 and C3 & 18 & 64,28 \\
Physics graph & C3 and C4 & 19 & 67,85 \\
Physics formula & C3 & 21 & 75,00 \\
\hline
\end{tabular}

In accordance with the data in table 4, further assessment of students' answers to the posttest questions, it appears that a large number of students have increased their understanding of physics diagram drawings correctly related to the concept of irregular straight motion (GLB), the concept of straight motion changes irregularly (GLBB), and parabolic motion. The ability of students has increased in applying mental physics 
models to understand and solve GLB, GLBB, and parabolic problems. In the post-test, students in general can answer the questions, both conceptual understanding, physics drawings, and physics graphs. Most students have no difficulty using physics formulas in solving mathematical physics problems. These results are in agreement with those reported by Mafiroh et al. (2017) that there is a positive linear relationship between mathematical representation skills and student learning outcomes (Mafiroh et al., 2017). The increase is related to student learning outcomes in solving questions at SWS. In accordance with the opinion of Trianto (2012) that training sessions in the direct learning process can be utilized to actively involve students, in this case it can be used for learning mental physics models to improve learning outcomes.

The mean score achieved by students in posttest increased to 71, 42. Posttest score increased by 26.78 or $60.00 \%$ of the pretest average score. This shows that the cognitive understanding of students in posttests is in a good category. Students can already use mental physics models to solve physics problems, especially in understanding physics conceptually, understanding physics diagrams, understanding physics graphs, and also understanding the use of physics formulas in the concepts of GLB and GLBB, and Parabolic motion. These findings are in line with those reported by Rohadi (2011) and Rohadi and Setiawan (2019). The application of inovative SWS in physics classroom activity could improve student's understandings and skills in solving physics problems.

\section{CONCLUSION}

The cognitive competence of the first semester students of physics education study program at JPMIPA FKIP UNIB 2019/2020 academic year is good enough in using mental physics models to solve GLB concept questions, GLBB concepts, and parabolic motion concepts conceptually, diagrams, graphically, and mathematically (Basic physics formulas). In this article descriptive analysis based on mental physics models is carried out on the cognitive competencies of students on the concepts of GLB, GLBB, and parabolic motion only, so for further studies it is necessary to do on other basic physics concepts. 


\section{REFERENCES}

Amrizaldi, A., Diantoro, M., \& Wartono, W. (2014). Pengembangan Tes Diagnostik Untuk Memetakan Model Mental Siswa Kelas X SMA/MAN Materi Suhu Dan Kalor. Prosiding Seminar Nasional Fisika (E-Journal), 27-31.

Gentner, D. \& Stevens, L. A. (1983). Mental Models (1st ed.). Psychology Press.

Gilbert, K. J., Osborn, J. R., \& Fensham, J. P. (1980). Children Science And Its Consequence For Teaching. Science Education, 66(4), 623-633.

Herlina, K., Nur, M., \& Widodo, W. (2014). Model Mental Mahasiswa dalam Memahami Pembiasan Cahaya dan Kaitannya dengan Kemampuan Memprediksi. Prosiding SNPS (Seminar Nasional Pendidikan Sains).

Khasanah, N., Wartono, W., \& Yuliati, L. (2016). Analysis Of Mental Model Of Students Using Isomorphic Problems In Dynamics Of Rotational Motion Topic. Jurnal Pendidikan IPA Indonesia, 5(2), 186-191.

Koto, I. (2004). Analisis Konsepsi Mahasiswa Fisika PMIPA UNIB Dalam Memahami Konsep Listrik Dinamis. Excacta Jurnal Pendidikan Matematika Dan Sains, 1(1), 24-27.

Mafiroh, I., Ertikanto, C., \& Wahyudi, I. (2017). Pengaruh Skill Representasi Matematis Terhadap Hasil Belajar Siswa Menggunakan Model Discovery Learning. Jurnal Pembelajaran Fisika, 5 (2), 57-68.

Nurhidayati, D., Feriansyah, S., \& Wahyudi, I. (2017). Perbandingan Penggunaan LKS (Predict-Observe-Explain) Dengan LKS Konvensional Terhadap Hasil Belajar. Jurnal Pembelajaran Fisika, 2 (2), 45-56.

Priyadi, R., Diantoro, M., \& Parno, P. (2018). Kajian Literatur: Model Mental Dan Metode Evaluasinya. Jurnal Pendidikan Sains, 6 (2), 70-75.

Rahayu, S., \& Purwanto, J. (2013). Identifikasi Model Mental Siswa SMA Kelas X Pada Materi Hukum Newton Tentang Gerak. Kaunia, 9 (2), 12-20.

Rohadi, N. (2011). Kompetensi Kognitif Mahasiswa Pendidikan Fisika FKIP UNIB Pada Konsep-Konsep Dasar Fisika. Excacta Jurnal Pendidikan Matematika Dan Sains, 12 (1), 80-86.

Rohadi, N. (2012). Pemahaman Konseptual Mahasiswa Pendidikan Fisika FKIP UNIB Pada Diagram Medan Elektromagnet. Excacta Jurnal Pendidikan Matematika Dan Sains, 1 (1), 119-123.

Rohadi, N., Herlina, I., \& Suwarsono, (2003). Penyusunan Bahan Ajar Terpadu Remediasi Menerapkan Model Genratif Untuk Mengatasi Kendala Kognitif Fisika SLTP Di Provinsi Bengkulu. Laporan Hibah Bersaing, LPPM UNIB.

Rohadi, N., \& Setiawan, I. (2019). Pembelajaran Langung Kinematika Partikel Berbasis Model Mental Fisika Untuk Meningkatkan Kompetensi Kognitif Mahasiswa Prodi Pendidikan Fisika Fkip Unib Tahun 2019/2020. Laporan PPKP FKIP UNIB. 
Swistoro, E. (2007). Konsepsi Mahasiswa Fisika Terhadap Pokok-Pokok Materi Fisika Dasar Pada Program Studi Pendidikan Fisika FKIP UNIB. Excacta Jurnal Pendidikan Matematika Dan Sains, 6 (1), 128-135.

Trianto, T. (2012). Mendesain Model Pembelajaran Inovatif-Progresif (5th ed.). Kencana Prenada Media Group.

Wiersma, W. (1986). Researh Methods In Education: An Introduction (4th ed.). Allyn and Bacon. 